\title{
Mitochondria-rich cells changes induced by nitrite exposure in tambaqui (Colossoma macropomum Cuvier, 1818)
}

\author{
OSCAR T.F. DA COSTA ${ }^{1}$, CLEVERSON A. RAMOS ${ }^{1}$, WALLICE P. DUNCAN ${ }^{1}$, \\ JULIANA L.V. LAMEIRAS ${ }^{2}$ and MARISA N. FERNANDES ${ }^{3}$ \\ ${ }^{1}$ Departamento de Morfologia, Universidade Federal do Amazonas, Avenida General \\ Rodrigo Octávio Jordão Ramos, 6200, 69077-000 Manaus, AM, Brazil \\ ${ }^{2}$ Programa de Pós-Graduação em Biotecnologia, Universidade Federal do Amazonas, Avenida \\ General Rodrigo Octávio Jordão Ramos, 6200, 69077-000 Manaus, AM, Brazil \\ ${ }^{3}$ Departamento de Ciências Fisiológicas, Universidade Federal de São Carlos, Rodovia \\ Washington Luis, Km 235, 13565-905 São Carlos, SP, Brazil \\ Manuscript received on September 26, 2016; accepted for publication on October 28, 2016
}

\begin{abstract}
The gill mitochondria-rich cells of the juvenile Amazonian fish Colossoma macropomum were analyzed using light and scanning and transmission electron microscopy after $96 \mathrm{~h}$ exposure to 0.04 and $0.2 \mathrm{mM}$ nitrite. Although the number of mitochondria-rich cells decreased significantly in the lamellar epithelium, no decrease was found in the interlamellar region of the gill filament. Nitrite exposure caused significant reduction on the apical surface area of individual mitochondria-rich cells $(\mathrm{p}<0.05)$, with a resulting reduction of the fractional area of these cells in both the lamellar and filament epithelium. Swelling of endoplasmic reticulum cisternae, nuclear envelope and mitochondria were the main changes found in the mitochondria-rich cells. Cristae lysis and matrix vacuolization characterized the mitochondrial changes. The overall ultrastructural changes indicated cellular functional disruption caused by exposure to nitrite. The changes observed in the gill indicate that the cellular structures involved in the process of energy production become severely damaged by exposure to nitrite indicating irreversible damage conducting to cell death.
\end{abstract}

Key words: cell damage, fish, gills, morphometry, ultrastructure.

\section{INTRODUCTION}

Nitrite $\left(\mathrm{NO}_{2}^{-}\right)$is an intermediate product of bacterial ammonia decomposition that occurs naturally in ecosystems. Normally, low environmental levels are maintained as a result of balanced bacteriadriven nitrification and denitrification processes

Correspondence to: Oscar Tadeu Ferreira da Costa

E-mail: oscarcostaufam@gmail.com
(Lewis Jr and Morris 1986, Jensen 2003). At low concentrations, $\mathrm{NO}_{2}^{-}$is beneficial for fish as an exogenous reservoir for nitric oxide, which is a key signaling molecule in cardiovascular regulation (Hansen and Jensen 2010, Jensen and Hansen 2011). High concentrations are related to mass fish mortality (Svobodová et al. 2005). Some environmental conditions such as temperature and 
high levels of organic matter favor the occasional development of $\mathrm{NO}_{2}{ }^{-}$in the Amazonian environment and in fish culture systems. The active mechanism for $\mathrm{NO}_{2}^{-}$uptake by the gill mitochondria-rich cells (MRCs) and its possible toxic effect on these cells were previously discussed (Jensen 2003, Williams and Eddy 1986, Gaino et al. 1984).

Nitrite enters the bloodstream via the same mechanism of $\mathrm{Cl}^{-}$uptake on gill MRCs. Inside the fish, $\mathrm{NO}_{2}^{-}$promotes methemoglobinemia, decreasing the $\mathrm{O}_{2}$-carrying capacity of the blood, and bioconcentrates in liver, brain, muscle, and gills, disrupting its functions (Margiocco et al. 1983, Jensen 2003, Tomasso 2012). In the present, scarce information is available on the ultrastructural changes leading to cell damage under $\mathrm{NO}_{2}^{-}$stress in freshwater fish. The main purpose of the study reported on herein was to evaluate the effect of $\mathrm{NO}_{2}^{-}$on the distribution and ultrastructure of the branchial MRCs of an Amazonian serrasalmid species, Colossoma macropomum Cuvier, 1818, which is locally known as tambaqui and inhabits waters with low levels of $\mathrm{Cl}^{-}$, low $\mathrm{pH}$ and, periodically hypoxic. This water-breathing species is intensively exploited in aquaculture programs but little is known about its tolerance to toxic compounds.

\section{MATERIALS AND METHODS}

\section{EXPERIMENTAL ANIMALS}

This study was conducted in accordance with national and institutional guidelines for the protection of human and animal welfare. Juvenile specimens of C. macropomum [body mass $=73.66$ $\pm 4.00 \mathrm{~g}$, mean \pm sem.], were obtained from Centro Nacional de Pesquisa e Conservação de Peixes Continentais (CEPTA, Pirassununga, Brazil, with permission from MMA/SISBIO; Protocol Num. 33918). Fish were kept indoors for at least 4 weeks in 1,000-liter holding tanks supplied with running aerated water (with a temperature of $21^{\circ} \mathrm{C}, \mathrm{pH}$ of
7.4, water $\mathrm{PO}_{2}>130 \mathrm{mmHg},\left[\mathrm{Ca}^{2+}\right]$ of $0.043 \mathrm{mM}$; $\left[\mathrm{Na}^{+}\right]$of $0.034 \mathrm{mM} ;\left[\mathrm{Cl}^{-}\right]<0.014 \mathrm{mM}$; and $\left[\mathrm{NO}_{2}^{-}\right]<$ $0.004 \mathrm{mM}$ ). The animals were fed daily to satiation with commercial fish food pellets. Excess of food decanted at the bottom of the tanks were removed by siphoning. Feeding was suspended two days before the experiments. The photoperiod adopted was $12 \mathrm{~h}$ of daylight and $12 \mathrm{~h}$ of night throughout the acclimation and experimental periods.

\section{NITRITE EXPOSURE}

Ten fish per treatment were placed in an experimental aquarium (with a volume of $63 \mathrm{~L}$ ) supplied with continuous aerated water from the same source as the holding water and acclimatized for $24 \mathrm{~h}$ prior to adding reagent-grade $\mathrm{NaNO}_{2}$ (Merck, Germany) to provide the selected concentrations of 0.04 and 0.2 $\mathrm{mM} \mathrm{NaNO}_{2} ; 96 \mathrm{~h} \mathrm{LC}_{50} \mathrm{NO}_{2}^{-}=0.16 \mathrm{mM}$ according to Costa et al. (2004). The $\mathrm{NO}_{2}^{-}$concentration was measured and adjusted according to Strickland and Parsons (1972). Similar tests without addition of $\mathrm{NO}_{2}^{-}$were used for control purposes. Observed deaths were reported. Following the $96 \mathrm{~h}$ exposure to $\mathrm{NO}_{2}^{-}$, the fish were removed from the test aquarium and anesthetized $(0.5 \%$ Benzocaine, Sigma-Aldrich, USA), and sacrificed with a blow to the head.

\section{SAMPLING AND TISSUE PROCESSING}

The second gill arch on the right-hand side was immediately excised and washed in a $0.9 \%$ salinesucrose solution. For light microscopy (LM), filaments $(n=6 /$ fish $)$ that were still attached to the septum of the arch were immersed in $4 \%$ paraformaldehyde, $1 \%$ glutaraldehyde in 0.1 $\mathrm{M}$ of phosphate-buffer saline ( $\mathrm{pH}$ 7.2) fixative solution for $24 \mathrm{~h}$. The samples were dehydrated and embedded in Historesin ${ }^{\circledR}$ (Leica, Heidelberg, Germany). Serial sections $1 \mathrm{~mm}$ thick, a constant distance of $40 \mathrm{~mm}$ apart, were obtained from the trailing edge to the leading edge of the filament 
(longitudinal sections perpendicular to the surface of the secondary lamella). Sections were stained with PAS (periodic acid-Schiff) reaction and subsequently $0.5 \%$ toluidine blue (Kiernan 2008) and analyzed under a BX-51 Olympus microscope equipped with a Panasonic DMC-FZ20 camera (Osaka, Japan).

For transmission electron microscopy, small fragments of filaments that contained lamellae were fixed in $2.5 \%$ glutaraldehyde solution buffered with $0.1 \mathrm{M}$ phosphate-buffer saline ( $\mathrm{pH}$ 7.3) for $2 \mathrm{~h}$. The samples were post-fixed in a $1 \%$ $\mathrm{OsO}_{4}$ solution, dehydrated with an acetone series, and embedded in Araldite 6005 (Ladd Research Industries, Inc., Burlington, VT, USA). Ultra-thin (60-70 $\mathrm{nm}$ thick) sections were contrasted with uranyl acetate and lead citrate and examined under a Philips CM 120 electron microscope. Sixteen photomicrographs from each fish were analyzed for cytological changes in MRCs, and the results were presented as semi-quantitative means of the ultrastructural changes observed.

For the scanning electron microscopy analysis, pairs of filaments attached to the septum were fixed in $2.5 \%$ glutaraldehyde solution buffered with 0.1 $\mathrm{M}$ phosphate-buffer saline ( $\mathrm{pH}$ 7.3) for $2 \mathrm{~h}$. The samples were dehydrated with a graded ethanol series up to pure ethanol and then $\mathrm{CO}_{2}$ criticalpoint dried. Filament pairs were glued with silver paint onto the specimen stub (the lateral side of the filaments parallel to the face plan of the stub plate), coated with gold in a vacuum sputterer and examined under a Zeiss DSM 940 scanning microscope at $25 \mathrm{kV}$.

\section{GILL MORPHOMETRY AND CELL COUNTS}

Morphometric analyses were performed on $1 \mathrm{~mm}$ thick serial sections stained with PAS- toluidine blue. Digitized images were analyzed using the SigmaScan software package (SYSTAT, Statistical and Graphical Software, CA, USA). During this analysis, a Merz test array (Merz 1967) was superimposed over the video monitor to ensure random orientation of the measurements on each section at a magnification of at approximately 1,400. The Merz intercepts with the borders of the lamellar epithelia and lamellar and filament epithelia were used to define the starting point for a two-points measurement [modified from (Audet and Wood 1993)]. The thickness of the lamellar and filamentar epithelium was measured from the surface in contact with the ambient water to the respective basement membrane. The thicknesses of the lamellae and filaments were measured from the external surface to the external surface of the respective region. Thirty randomly located measurements were performed per fish. The frequency of MRCs was counted on five consecutive lamellae and respective interlamellar regions of filaments on three different filaments per fish (90 measurements/fish). All cell counts and measurements were performed using a randomized blind method in which the counter did not know whether tissue sections were from $\mathrm{NO}_{2}{ }^{-}$-treated experimental or untreated control animals.

Measurements of the apical surface area of MRCs were performed on the trailing edges of the filaments (10-20 lamellae distal from the septum) using scanning electron microscopy. The apical surface area was determined by tracing the cell perimeter on a calibrated digitizer tablet using the SigmaScan software package (SYSTAT, Statistical and Graphical Software, CA, USA) according to (Bindon et al. 1994). Random areas were recorded at a magnification of approximately 1,500. The apical MRC area was used to calculate the MRCs fractional surface area (FSA, i.e., the fraction of the gill filament epithelial surface that was occupied by MRCs) and the cell density according to the following equations: 


\section{STATISTICAL ANALYSES}

All data are expressed as the mean \pm sem (standard error of the mean) unless stated otherwise. The statistical significance between data sets was determined using one-way ANOVA followed by Bonferroni post hoc test with a significant level of $5 \%$. Statistical analyses were performed using the SigmaStat software package (SYSTAT, Statistical and Graphical Software, CA, USA).

\section{RESULTS}

Mortality after $96 \mathrm{~h}$ of $\mathrm{NO}_{2}^{-}$exposure was 20 and $60 \%$ (0.04 and $0.2 \mathrm{mM}$, respectively). No deaths were observed in the control group.

The morphology of gill filaments and lamellae of C. macropomum (Figure 1a-c) is similar to that described for other teleost species. The secondary lamellae were regularly spaced on both sides of the gill filaments and consisted of two epithelial layers of cells separated by rows of pillar cells interspersed with blood spaces. The control fish of this species exhibited numerous MRCs on their lamellae (Figure 1a). Fish exposed to $0.04 \mathrm{mM}$ presented thinner and longer lamellae interspersed with protruding and swollen MRCs with varied morphologies. Pillar cells flanges were apparently retracted, thus revealing increased vessel space (Figure 1b). At a higher level of $\mathrm{NO}_{2}^{-}$exposure $(0.2 \mathrm{mM})$, filaments had a slender appearance. The filament epithelium was only 3-4 cells thicker (Figure 1c) and thickness of lamella was reduced in more than $30 \%$ (Figure 1d). Following these changes, we observed a significant decrease in the thickness of epithelium of lamella, approximately $40 \%$ for both $\mathrm{NO}_{2}^{-}$exposures (Figure 1e). The thickness of filament was significantly reduced after exposure to $\mathrm{NO}_{2}^{-}(16 \%$ and $31 \%$, respectively, in fish exposed to 0.04 and $0.2 \mathrm{mM}$ ) (Figure 1f). The filamentar epithelium was reduced by $25 \%$ and 42 $\%$ following the same pattern previously reported (Figure 1g). Nitrite exposure reduced the frequency of MRCs on lamella approximately 51-57 \% (Figure 1h), but no significant changes in the frequency of these cells on the filament (interlamellar region) were observed (Figure 1i).

Nitrite stress resulted in slender shape lamellae; more pronounced at higher concentration tested (Figure 2a-c). Nitrite exposure reduced the FSA and the apical surface area of MRCs approximately $30 \%$ (Figure $2 \mathrm{~d}-\mathrm{e}$ ). No change in the density of the MRCs on filaments was observed (Figure 2f).

Table I summarizes the cytological analysis of MRCs of control C. macropomum and fish exposed to $\mathrm{NO}_{2}^{-}$for $96 \mathrm{~h}$. Ultrastructure of MRCs from the control group was characterized by a high mitochondrial density in the cytoplasm and an extensive and anastomosing tubular system. The cisternae of endoplasmic reticulum (ER) were discreetly distributed throughout the cytoplasm. The mature MRC presented mitochondria with ellipsoidal shapes and extensive but not dilated cisternae of the crista. Spherical vesicles were dispersed in the cytoplasm. Nuclear euchromatin was prevalent over electron-dense heterochromatin. The large majority of MRCs was totally exposed to ambient water, but some cells remained retracted surrounded by flattened pavement cells (Figure 3a). Fish exposed to $0.04 \mathrm{mM}$ (Figure 3b) exhibited MRCs with pronounced distension of the tubular system, ER and proliferation of lysosome-like bodies. The mitochondria were characterized by distention of the mitochondrial matrix, which was frequently filled with dense bodies. The nuclei displayed slight deformation of the nuclear envelope (dilation of the perinuclear space). Many cells presented a low electron-density and scarcity of organelles at the basolateral region. The apical surface of the MRCs in contact with the ambient water was frequently restricted by projections from pavement cells. Many MRCs presented cellular and organelle swelling. In fish exposed to $0.2 \mathrm{mM}$ (Figure $3 \mathrm{c}$ ), the previous related alterations were more pronounced. The cells reached the maximum 

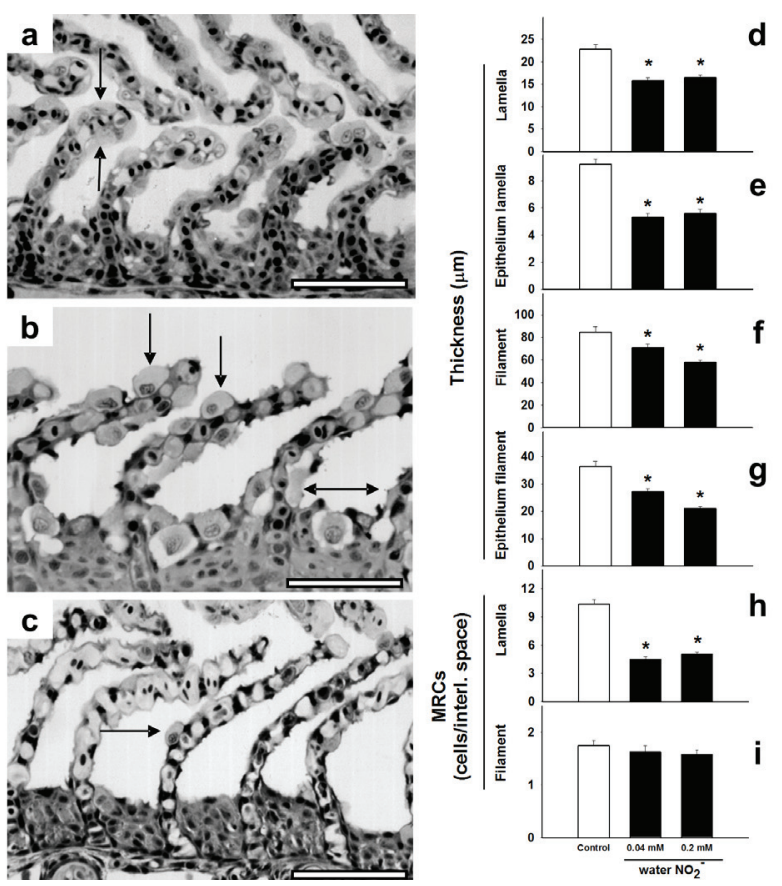

Figure 1 - Light micrographs and morphometry of gills of C. macropomum. a. Filament and lamellae from the control group exhibited numerous MRCs (arrows) and swollen and short lamellae. MRCs are easily distinguished in this resin section because of their round shapes. b. $0.04 \mathrm{mM} \mathrm{NO}_{2}$ : these lamellae were characterized by a gradual decrease in the number of MRCs and increased interlamellar space (double arrowhead). Some MRCs exhibit swelling and visible changes in the nuclear material. c. $0.2 \mathrm{mM} \mathrm{NO}_{2}-$ : scarce MRCs were observed on lamellae. d. Thickness of lamellae; e. Thickness of lamellar epithelium; f. Thickness of filament; g. Thickness of filament epithelium. h. Frequency of MRCs on lamellae and (i) filament. *Significantly different $(\mathrm{p}<0.05)$ from control. Scale bars $=25 \mu \mathrm{m}$

swelling and internally were characterized by progressive loss of organelles and membrane breakdown charactering necrosis.

\section{DISCUSSION}

Our results showed that $\mathrm{NO}_{2}^{-}$exposure of $C$. macropomum promoted morphological changes in the gill epithelium and damage of MRCs. In general, these results confirmed the high sensitivity of C. macropomum to $\mathrm{NO}_{2}^{-}$reported by Costa et al. (2004) where hemolytic anemia was the main change observed in fish blood. These morphological
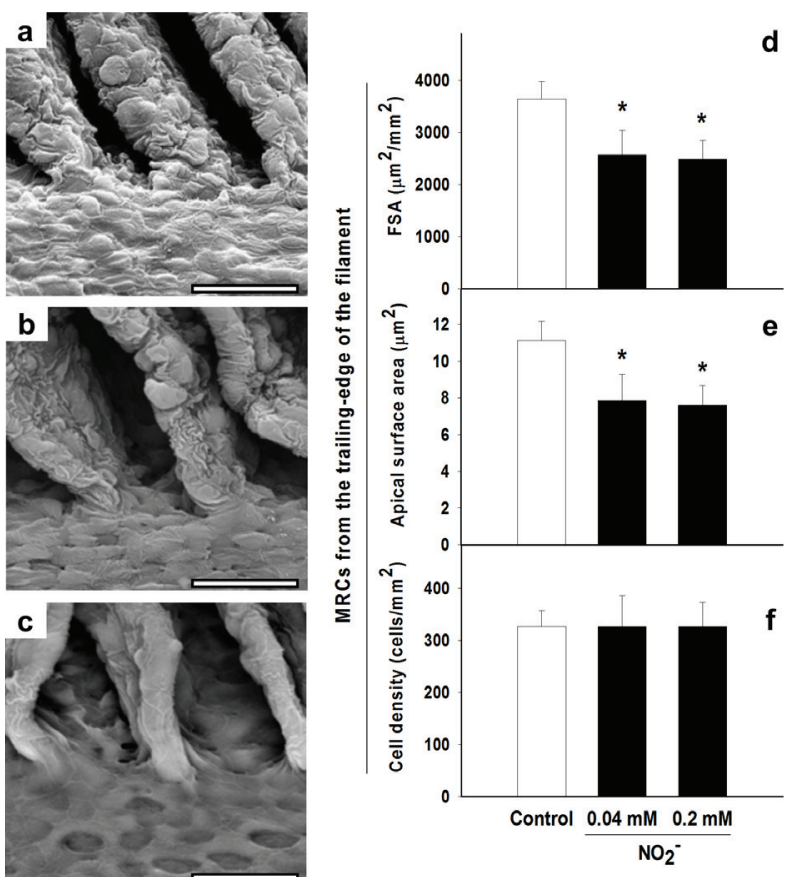

Figure 2 - SEM and surface measurements of gills of $C$. macropomum. a. Control group. b. $0.04 \mathrm{mM} \mathrm{NO}_{2}^{-}$. c. $0.2 \mathrm{mM}$ $\mathrm{NO}_{2}^{-}$. Note the changes in the structure of lamellae and filament surface after exposure to $\mathrm{NO}_{2}{ }^{-}$. d. MRC fractional surface area. e. Apical surface area. f. MRC density. *Significantly different $(\mathrm{p}<0.05)$ from control. Scale bars $=10 \mu \mathrm{m}$.

findings are potential inducers of severe ion and osmoregulation disturbance in freshwater fish living in ion poor water.

Effects of $\mathrm{NO}_{2}^{-}$exposure on fish ionic homeostasis are relatively well-known (Jensen et al. 1987, Knudsen and Jensen 1997, Lewis Jr and Morris 1986, Martinez and Souza 2002, Svobodová et al. 2005, Williams and Eddy 1986). The MRCs are the main cell responsible for ion exchange across gill membranes and is the first target for $\mathrm{NO}_{2}^{-}$action and where it accumulates and is made available to the bloodstream. In this study, MRCs were lost from lamellae and its apical surface area was reduced suggesting decreased ion uptake (Evans et al. 2005). This decrease in contact with ambient water was promoting by cytoplasmic projections of PVCs overlapping MRCs, such condition also imply reduced involvement with ionic regulation (Marshall et al. 1997). 

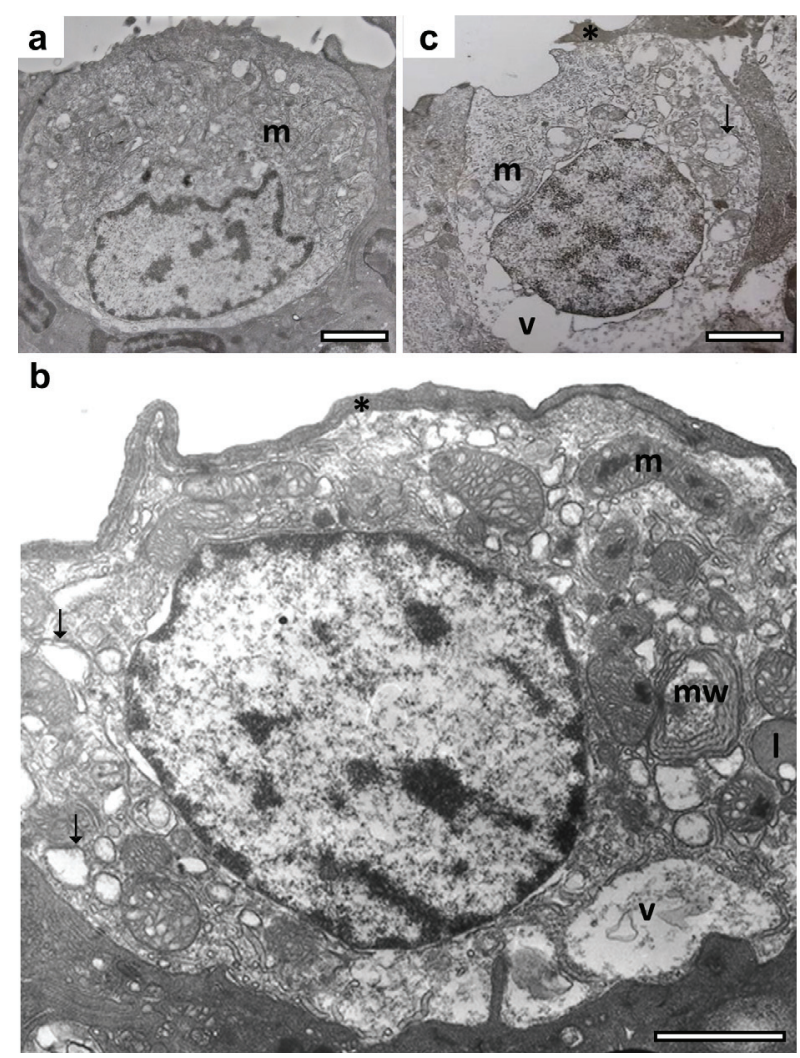

Figure 3 - TEM of MRCs from lamellae of C. macropomum. a. Control group. b. $0.04 \mathrm{mM} \mathrm{NO}_{2}{ }^{-}$.c. $0.2 \mathrm{mM} \mathrm{NO}_{2}{ }^{-}$. Hypertrophic MRCs were filled with distend and dense mitochondria (m), distend tubular system (arrow), lysosome-like bodies (1), myelin whorls (mw) and large vacuoles $(\mathrm{v}){ }^{*}=$ extension of pavement cell. Scale bars: $\mathrm{a}, \mathrm{c}=1 \mu \mathrm{m} ; \mathrm{b}=5 \mu \mathrm{m}$.

The high density of MRCs in the lamellar epithelium of C. macropomum of the control group may be due to the low ion concentration in the environmental water, which characterizes Brazil's continental waters. Several studies have shown high MRCs proliferation in fish living in ion-poor water (Perry 1997), although Fernandes and PernaMartins (2002) noted the significantly variable number of MRCs in Brazil's freshwater fish.

The sharp reduction of MRCs in lamellar epithelium may be related to increased cell death and low cellular differentiation in this epithelium. Indeed, most of the ultrastructural changes in MRCs displayed a morphological pattern of necrosis. Previous studies have suggested that $\mathrm{NO}_{2}^{-}$increases MRCs activity to maintain ion homeostasis (Gaino
TABLE I

Ultrastructural changes in the gill MRCs of $C$. macropomum after exposure to $\mathrm{NO}_{2}^{-}$concentrations for $96 \mathrm{~h}$.

\begin{tabular}{|c|c|c|c|}
\hline \multirow{2}{*}{$\begin{array}{l}\text { Cytological } \\
\text { Parameters }\end{array}$} & \multicolumn{3}{|c|}{$\left[\mathrm{NO}_{2}^{-}\right](\mathrm{mM})$} \\
\hline & 0.00 & 0.04 & 0.20 \\
\hline \multicolumn{4}{|l|}{ Nuclei } \\
\hline $\begin{array}{l}\text { Deformation of } \\
\text { nuclear envelope }\end{array}$ & - & ++ & ++++ \\
\hline $\begin{array}{l}\text { Dilation of nuclear } \\
\text { envelope cisternae }\end{array}$ & - & ++ & ++++ \\
\hline \multicolumn{4}{|l|}{ Tubular system } \\
\hline Overall amount & ++ & +++ & ++++ \\
\hline Dilation of cisternae & - & +++ & ++++ \\
\hline $\begin{array}{l}\text { Fragmentation of } \\
\text { cisternae }\end{array}$ & - & +++ & +++ \\
\hline \multicolumn{4}{|l|}{ Lysosomal elements } \\
\hline Overall amount & + & ++ & +++ \\
\hline Myelinated bodies & $+/-$ & ++ & +++ \\
\hline Cytoplasmic vacuoles & ++ & ++ & +++ \\
\hline \multicolumn{4}{|l|}{ Mitochondria } \\
\hline Overall amount & ++++ & +++ & ++ \\
\hline $\begin{array}{l}\text { Morphological } \\
\text { heterogeneity }\end{array}$ & - & ++ & +++ \\
\hline $\begin{array}{l}\text { Formation of myelin- } \\
\text { like whorls }\end{array}$ & - & ++ & +++ \\
\hline Vacuolization & - & ++ & +++ \\
\hline $\begin{array}{l}\text { Outer membrane } \\
\text { rupture }\end{array}$ & - & - & ++ \\
\hline
\end{tabular}

Coding: -, absent; +/-, very little developed; +, little developed; ++ , moderately developed; +++, strongly developed; ++++, very strongly developed.

et al. 1984), which, in combination with the direct toxic effects of $\mathrm{NO}_{2}{ }^{-}$, contributes to reduce the cell's cycle.

Our results are, in general, congruent with those found in the ultrastructure of MRCs of Oncorhynchus mykiss exposed to $450 \mu \mathrm{gN}-\mathrm{NO}_{2} / \mathrm{L}$ 
(0.03 $\mathrm{mM} \mathrm{NO}_{2}^{-}$) for $72 \mathrm{~h}$ (Gaino et al. 1984). Furthermore, we also found signs of severe damage in mitochondria after $\mathrm{NO}_{2}^{-}$exposure, evidencing clear irreversible cellular damage. Mitochondria is a target for $\mathrm{NO}_{2}^{-}$binding (Shiva 2010). Nitrite binds to heme moieties of mitochondrial cytochrome components of the respiratory chain, inhibiting respiration, and stopping or reducing ATP production (Jensen et al. 2015). Mitochondrial swelling has been related to the toxic action of compounds deriving from $\mathrm{NO}_{2}^{-}$in rat liver hepatocytes (Rusu et al. 1979).

Cell and organelle swelling, as reported in our study, possibly reflect the inhibition of $\mathrm{Na}^{+} /$ $\mathrm{K}^{+}$ATPase, promoting in cell $\mathrm{K}^{+}$efflux and $\mathrm{Na}^{+}$ uptake, as previously reported in C. carpio (Knudsen and Jensen 1997, Jensen et al. 1987). In addition to osmotic changes, $\mathrm{NO}_{2}^{-}$at high concentrations in tissue causes an excess of NO generation resulting in excessive induction of ironnitrosylation, nitrosation of cellular thiols and amines, exacerbating $\mathrm{NO}_{2}{ }^{-}$toxicity and interfering with the functioning of many key proteins (Jensen et al. 2015).

In our study, we present evidence that cell death by non-apoptotic program (necrosis) was prevalent and is not morphologically different from that described for other species exposed to toxic substances (Mallatt 1985) or following transfer from fresh water to seawater (Bonga and Van der Meij 1989). Evidences indicate that necrosis is the main cell death program triggered when ATP levels drop rapidly after $\mathrm{NO}_{2}^{-}$stress (Leist et al. 1997, Brown and Borutaite 2002, Leist et al. 1999). In opposition to other studies, few cells were demised from epithelia by apoptosis, however, this cell death program has been reported after $\mathrm{NO}_{2}^{-}$ intoxication in fish (Jia et al. 2015, Sun et al. 2014). The prevalence of necrotic MRCs may evidence variability in energy use of cells or may indicate different levels of mitochondrial damage which may trigger one or the other mechanism of cell death.

In conclusion, MRCs are particularly affected by $\mathrm{NO}_{2}^{-}$exposure. The changes observed in this study indicate that $\mathrm{NO}_{2}{ }^{-}$is toxic to C. macropomum and has a potential to affect important physiological process by disrupting the MRC ultrastructure and its distribution along the branchial epithelium. The changes observed in the gill indicate that the cellular structures involved in the process of energy production become severely damaged by exposure to $\mathrm{NO}_{2}^{-}$indicating irreversible damage resulting in cell death.

\section{ACKNOWLEDGMENTS}

This work was supported by Conselho Nacional de Desenvolvimento Científico e Tecnológico (CNPq) and Coordenação de Aperfeiçoamento de Pessoal de Nível Superior (CAPES). We gratefully acknowledge the technicians of the Laboratório de Caracterização Estrutural (LCE, UFSCar) for their assistance and Centro Nacional de Pesquisa e Conservação de Peixes Continentais (CEPTA) for providing the fish, and Fundação de Amparo à Pesquisa do Estado do Amazonas (FAPEAM) for financial support (Grant number 062.00821/2014/ PAPAC). Marisa N. Fernandes is the recipient of a research fellowship from CNPq. Juliana L. V. Lameiras is the recipient of a postgraduate fellowship from CAPES.

\section{REFERENCES}

AUDET C AND WOOD CM. 1993. Branchial morphological and endocrine responses of rainbow trout (Oncorhynchus mykiss) to a long-term sublethal acid exposure in which acclimation did not occur. Can J Fish Aquat Sci 50: 198-209.

BINDON S, GILMOUR K, FENWICK J AND PERRY S. 1994. The effects of branchial chloride cell proliferation on respiratory function in the rainbow trout Oncorhynchus mykiss. J Exp Biol 197: 47-63.

BONGA SW AND VAN DER MEIJ C. 1989. Degeneration and death, by apoptosis and necrosis, of the pavement 
and chloride cells in the gills of the teleost Oreochromis mossambicus. Cell Tissue Res 255: 235-243.

BROWN GC AND BORUTAITE V. 2002. Nitric oxide inhibition of mitochondrial respiration and its role in cell death. Free Radic Biol Med 33: 1440-1450.

COSTA OTF, FERREIRA DJS, MENDONÇA FLP AND FERNANDES MN. 2004. Susceptibility of the Amazonian fish, Colossoma macropomum (Serrasalminae), to shortterm exposure to nitrite. Aquaculture 232: 627-636.

EVANS DH, PIERMARINI PM AND CHOE KP. 2005. The multifunctional fish gill: dominant site of gas exchange, osmoregulation, acid-base regulation, and excretion of nitrogenous waste. Physiol Rev 85: 97-177.

FERNANDES MN AND PERNA-MARTINS SA. 2002. Chloride cell responses to long-term exposure to distilled and hard water in the gill of the armored catfish, Hypostomus tietensis (Loricariidae). Acta Zoo 83: 321-328.

GAINO E, ARILLO A AND MENSI P. 1984. Involvement of the gill chloride cells of trout under acute nitrite intoxication. Comp Biochem Physiol A: Physiol 77: 611-617.

HANSEN MN AND JENSEN FB. 2010. Nitric oxide metabolites in goldfish under normoxic and hypoxic conditions. J Exp Biol 213: 3593-3602.

JENSEN FB. 2003. Nitrite disrupts multiple physiological functions in aquatic animals. Comp Biochem Physiol A: Mol Integr Physiol 135: 9-24.

JENSEN FB, ANDERSEN NA AND HEISLER N. 1987. Effects of nitrite exposure on blood respiratory properties, acid-base and electrolyte regulation in the carp (Cyprinus carpio). J Comp Physiol B 157: 533-541.

JENSEN FB, GERBER L, HANSEN MN AND MADSEN SS. 2015. Metabolic fates and effects of nitrite in brown trout under normoxic and hypoxic conditions: blood and tissue nitrite metabolism and interactions with branchial NOS, Na+/K+-ATPase and hsp70 expression. J Exp Biol 218: 2015-2022.

JENSEN FB AND HANSEN MN. 2011. Differential uptake and metabolism of nitrite in normoxic and hypoxic goldfish. Aquat Toxicol 101: 318-325.

JIA R, HAN C, LEI J-L, LIU B-L, HUANG B, HUO H-H AND YIN S-T. 2015. Effects of nitrite exposure on haematological parameters, oxidative stress and apoptosis in juvenile turbot (Scophthalmus maximus). Aquat Toxicol 169: 1-9.

KIERNAN JA. 2008. Histological and histochemical methods: theory and practice. $4^{\text {th }}$ ed., U. K.: Scion - Bloxham.

KNUDSEN PK AND JENSEN FB. 1997. Recovery from nitrite-induced methaemoglobinaemia and potassium balance disturbances in carp. Fish Physiol Biochem 16: 1-10.

LEIST M, SINGLE B, CASTOLDI AF, KÜHNLE S AND NICOTERA P. 1997. Intracellular adenosine triphosphate (ATP) concentration: a switch in the decision between apoptosis and necrosis. J Exp Med 185: 1481-1486.
LEIST M, SINGLE B, NAUMANN H, FAVA E, SIMON B, KÜHNLES AND NICOTERAP. 1999. Nitric oxide inhibits execution of apoptosis at two distinct ATP-dependent steps upstream and downstream of mitochondrial cytochrome c release. Biochem Biophys Res Commun 258: 215-221.

LEWIS JR WM AND MORRIS DP. 1986. Toxicity of nitrite to fish: a review. Trans Am Fish Soc 115: 183-195.

MALLATT J. 1985. Fish gill structural changes induced by toxicants and other irritants: a statistical review. Can J Fish Aquat Sci 42: 630-648.

MARGIOCCO C, ARILLO A, MENSI P AND SCHENONE G. 1983. Nitrite bioaccumulation in Salmo gairdneri Rich. and hematological consequences. Aquat Toxicol 3: 261-270.

MARSHALL WS, BRYSON SE, DARLING P, WHITTEN C, PATRICK M, WILKIE M, WOOD CM AND BUCKLAND-NICKS J. 1997. $\mathrm{NaCl}$ transport and ultrastructure of opercular epithelium from a freshwateradapted euryhaline teleost, Fundulus heteroclitus. J Exp Zool 277: 23-37.

MARTINEZ CB AND SOUZA MM. 2002. Acute effects of nitrite on ion regulation in two neotropical fish species. Comp Biochem Physiol A: Mol Integr Physiol 133: 151-160.

MERZ WA. 1967. Die Streckenmessungen an gerichteten Strukturen im Mikroskop und ihre Anwendung zur Bestimmung von Oberflächen-Volumen-Relationen im Knochengewebe. Mikroskopie 22: 132-142.

PERRY SF. 1997. The chloride cell: structure and function in the gills of freshwater fishes. Annu Rev Physiol 59: 325-347.

RUSU M, PREDA N, GRACIUN C, GADALEANU V AND BUCUR N. 1979. Histoenzymological and ultrastructural changes in rats following the administration of aminopyrine and nitrite (nitrosoaminopyrine). IARC Sci Publ: 803-812.

SHIVA S. 2010. Mitochondria as metabolizers and targets of nitrite. Nitric Oxide 22: 64-74.

STRICKLAND JDH AND PARSONS TR. 1972. A Practical Handbook of Seawater Analysis. $2^{\text {nd }}$ ed., Ottawa: Bulletin 167. Fish Res B Can, 310 p.

SUN S, ZHU J, GE X, ZHANG C, MIAO L AND JIANG X. 2014. Cloning and expression analysis of a heat shock protein $90 \beta$ isoform gene from the gills of Wuchang bream (Megalobrama amblycephala Yih) subjected to nitrite stress. Gen Mol Res 14: 3036-3051.

SVOBODOVÁ Z, MÁCHOVÁ J, DRASTICHOVÁ J, GROCH L, LUSKOVÁ V, POLESZCZUK G, VELÍŠEK J AND KROUPOVÁ H. 2005. Haematological and biochemical profiles of carp blood following nitrite exposure at different concentrations of chloride. Aquacult Res 36: 1177-1184.

TOMASSO J. 2012. Environmental nitrite and aquaculture: a perspective. Aquacult Int 20: 1107-1116.

WILLIAMS EM AND EDDY FB. 1986. Chloride uptake in freshwater teleosts and its relationship to nitrite uptake and toxicity. J Comp Physiol B 156: 867-872. 